\title{
Czech Film After 1989
}

\author{
By Jiří Voráč \\ Spring 1997 Issue of KINEMA
}

\section{CZECH FILM AFTER 1989: THE WAVE OF THE YOUNG NEWCOMERS}

THE history of Czech cinema has been frequently marked and stigmatized, more than the non- industrial and more individual art disciplines, by large historical social upheavals which the Czech lands experienced in this century. During its hundred-year-long history, the Czech film survived five different social systems. Its origins (the first films on the Czech soil were presented by Jan Kř́ženecký in 1898) are rooted in the era of the Austro-Hungarian Empire. After the First World War, it continued its development in a free and democratic Czechoslovak Republic which was after two decades destroyed by the Nazi Germany. A fundamental systemic change occurred in 1945 when the Czechoslovak film was nationalized i.e., that the state (and after 1948 the Communist establishment) completely controlled all film activities in the entire country. ${ }^{(1)}$ After the demise of the Communist dictatorship in 1989, a democratic regime was reestablished and with it the market economy; the film production was privatized and returned to the hands of private producers and distributors. ${ }^{(2)}$ This dependency of the Czech film production on external conditions which were preventing the natural, continuous and intrinsic development of the film art was intensified by a specifically Czech cultural tradition which often preferred the social and educational function of art over its aesthetic function.

In critical periods of Czech history, culture and art became a major tool of resistance against national or political oppression. Under such circumstances, the cultural life was actually the only remaining outlet and assumed various functions of the political life which was unable to evolve normally. These circumstances attributed to the Czech art, more precisely Czech artists and intellectuals, the role of "moral representation" which substituted the missing political representation. Artists then became not only creators of objects d'art but also spokespersons articulating national and civic interests. Consequently, art as such fused its aesthetic dimension with social and political dimension. This instrumental function of art intensified during the totalitarian Communist rule (1948-1989) and culminated in 1989 when the Czech artists assumed a fundamental role in the destruction of the Communist system. Paradoxically, in the 1950s, and then again in the 1970s, during the two harshest periods of the Communist rule, the Czech film was forced into the role of a Communist propaganda tool. Thus the history of the Czech film was developing under the influence of discontinuity and permanent struggle. Periods of voluntary or involuntary service to the society alternated with efforts for emancipation of film as an independent art form. The result of this historical determination has been that Czech cinema, during the entire period of its existence, never had enough time and space for its full and natural development. This, among other things, led to the fact that the Czech film reached only exceptionally, and in a few individual instances, beyond its own borders, addressed foreign audiences, not to mention influencing the events of world cinema.

The first major success of the Czech film, at home and abroad, took place in the 1930s, triggered by the unusual success of the director Gustav Machatý and his film Ecstasy (Extáze, 1933) at the Venice Biennale in 1934. His film, starring Hedy Kiessler (Lamarr) created sensation with his daring erotic scenes which included images of frontal female nudity. Director Josef Rovenský and his more traditionally conceived lyrical, romantic picture River (1933), was also very successful. Both films shared Venice's Prize for Best Direction, "for extraordinary efficiency achieved through the simplest narrative means, and for a sensitive and spontaneous grasp of nature," according to the verdict of the Jury. Sensualism and lyricism, together with image qualities achieved through the outdoor photography of the Czech landscape, have been understood world-wide as typical characteristics of the Czech film school.

The Czech film experienced its golden age in the 1960s when for several years it basked in the spotlight of the world's interest. International critique of the period wrote about "the Czech film miracle." This was linked, before all, to the group of artists such as Miloš Forman, Ivan Passer, Věra Chytilová, and Jiří Menzel. This generation, called the "Czech New Wave," came forward in 1963. ${ }^{(3)}$ This "great harvest" of the Czech film peaked between 1965 and 1967 when The Shop on the Main Street (Obchod na korze by Ján Kádár and Elmar Klos, 1965) and Closely Watched Trains (Ostře sledované vlaky by Jiř́ Menzel, 1966) received 
American Academy Awards for the Best Foreign Language Film. Two other films, both by Forman, received Academy Award nominations: Loves of a Blonde (Lásky jedné plavovlásky, 1966) and Firemen's Ball (Hoř́, má panenko, 1968).

Not less important than international recognition was the fact that the Czech film achieved its own aesthetic emancipation. It cast off its ideological straitjacket, opened itself up to the past traumas as well as to the contemporary everyday reality. In the aesthetic sphere, it developed in an original way stimuli of the cinéma vérité and the French New Wave.

The boom of the Czech film of the 1960s was halted by the 1968 Soviet occupation which resulted in the neo-Stalinist period of the so-called normalization regime. At that time, the Czech New Wave was practically past its peak but that did not change the fact that, at the end of the 1960s and beginning of the 1970s, there occurred another severe break of continuity and that the Czech film found itself again, for the next two decades, under ideological dictate and international isolation.

The entire creative top of the Czech film were demolished: Some filmmakers went into exile (Forman, Passer, Kádár, Jasný and others), others remained in the country but was for several years not allowed to shoot. When, in the second half of the 1970s, they were gradually allowed to come back into the studios, they were unable to match the quality of their earlier films (e.g. Chytilová, Menzel).

It was the new generation which managed to link successfully, at the end of the 1980s and the beginning of the 1990s with the glorious periods of the Czech film history. This generation, however, had to assert itself in radically changed conditions of open society and market economy.

\section{II.}

After the Velvet Revolution in November 1989, Czech cinema, like the entire Czech society, went through a fundamental systemic transformation. In the first place, the state film monopoly, which since the 1945 nationalization guaranteed an uninterrupted film production, was abolished. The most visible manifestation of the arrival of market mechanisms was the decline of the national film output and the transformation of the genre structure. ${ }^{(4)}$ Dramatic changes influencing the society as a whole also caused the drop in viewer numbers and a marked change in their interest preferences. ${ }^{(5)}$ The dynamism of the transformation into a democratic society paradoxically caused a thematic crisis and the absence of suitable subjects.

The new freedom actually removed one of the important stimuli of the artistic creativity -- the critical reflection of the social and political status quo -- which had elevated the artistic act to a political act. The socio-political dimension of the art which used to be a legitimate part of the progressive creativity was taken over by standard political structures. As a result, the art and the artist have lost their specific privilege and untouchable status, which was defined by the historical development and geopolitical conditions of existence of the Czech nation.

These changes have required entirely new -- in the Czech Republic hitherto unusual -- changes on the part of filmmakers, who now had an unrestricted freedom of expression but became subordinated to market mechanisms. These events caused a psychological shock especially in the oldest generation (Chytilová, Menzel) and part of the middle generation. Today, these filmmakers do little shooting and their films generate a limited response. ${ }^{(6)}$ The rest of the middle generation, on the contrary, grasped the new opportunity, and has been quite openly cultivating filmmaking as business. These filmmakers are producing strictly commercial films linking with the most base traditions of the Czech film pulp or the American "B" movies.

\section{III.}

It was the generation of the young newcomers which managed best to adapt to the new conditions without artistic or moral decline. This generation which in the last seven years has counted nearly thirty new artists, has revived the stagnating Czech film, both through its numbers and the quality of its works. It is a well educated generation, cultivated through both classical and postmodern cultures, which has evident ambitions and is able to realize them. This generation, through its best films, brought the Czech film back onto the international stage, for example, through Jan Svěrák's Oscar-winning film Kolya (Kolja, 1996). It is not only a generational appurtenance when I say that all the remarkable projects of the post-1989 period are exclusively of this young generation. 
A first wave of this new generation which can be called the Generation of 1989, emerged towards the end of 1980s, during the period of the mortal agony of the Communist system. The Czech film, too, was in a deep agony at that time. The young debuting artists introduced something unusual and disturbing: A critical generational statement based on an open critical reflection of the status quo. Through their best works, this generation was able to go beyond the framework of the period-conditioned experience; they convincingly portrayed a universally valid conflict between the individual and society. Two films are particularly pertinent in this context: Irena Pavlásková's The Time of Servants $(\check{C}$ as sluhü, 1989)(7) and Vojtěch, Called Orphan (Vojtěch řěcený sirotek, 1989) by Zdeněk Tyc. ${ }^{(8)}$

A second wave surfaced at the beginning of the 1990s in already significantly altered social conditions; therefore, it somewhat differs from the first one. It has distanced itself from socially- critical themes. It has been favoring more intimate and at the same time, universal subjects. This generation moved from "appelativity" to "emotivity," from the film as a personal confession to the film-play and film-narration, from the intellectual film to the viewers' film that entertains.

Other remarkable talents of this group include: Vladimír Michálek (b. 1956) whose America (Amerika, 1994), an adaptation of Franz Kafka's unfinished novel caught critical attention; Jan Hřebejk (b. 1967), the author of the musical nostalgia-comedy Years of the Jackal ( ̌́akali léta, 1993) situated in Prague of the 1950s; Petr Zelenka (b. 1967), the author of the fictional "mystification" document about the journey of a provincial rock-group to the summit of show-business' fame (Mñága - Happy End, 1996; prize at the FF in Cottbus, Germany, 1996); Petr Václav (b. 1967), whose first film, the rough, sociological document Marian (1996) received the Silver Leopard at the IFF Locarno, 1996).

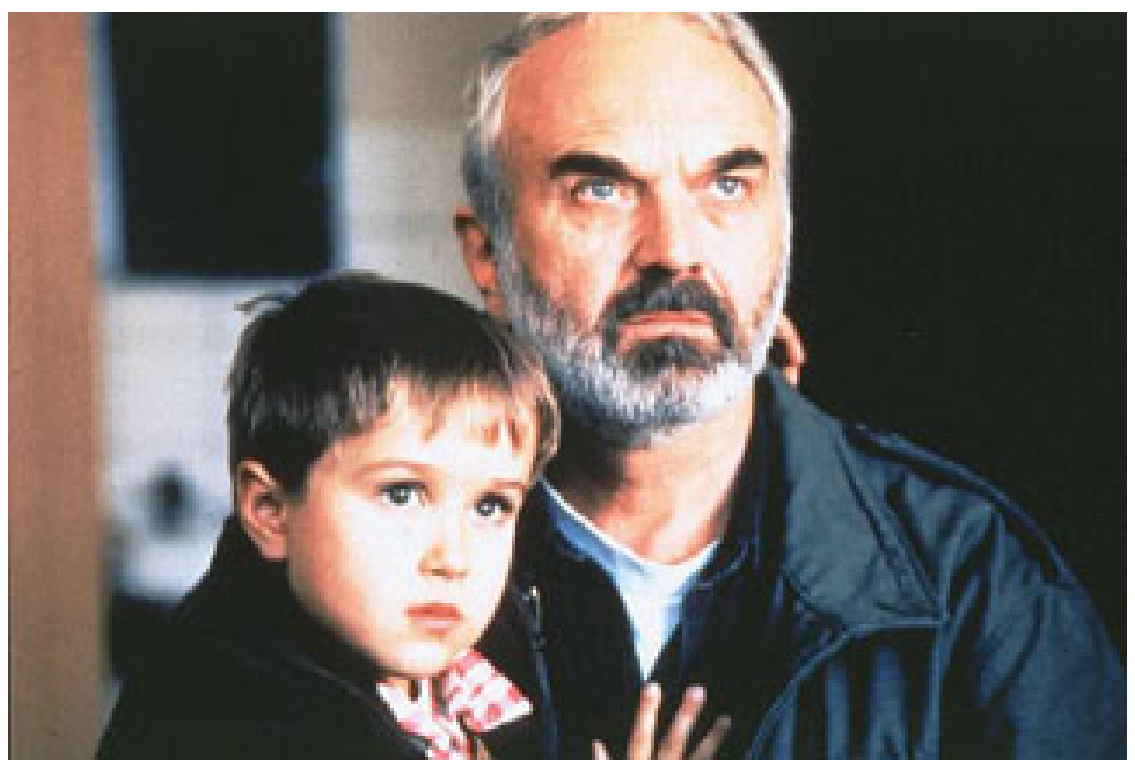

Figure 1: Kolya (Andrej Chalimon, l.) and Zdeněk Svěrák

The most conspicuous personalities of this generation seem to be, at this point, Jan Sverák ${ }^{(9)}$ and Saša Gedeon. ${ }^{(10)}$ These two filmmakers have in common a strikingly natural film sense -- a visual sense of a poetic nature, the gift of observation, a narrative ease, vitality and refined humour. As personalities, however, and as to their artistic ambitions, they are quite different and they represent two distinct types of the contemporary activities of Czech cinema.

Against Svěrák's panache and tenacity stands Gedeon's quiet status of an outsider. Svěrák is before all a talented director and filmmaker. This is related to his expansive universality (every one of his project represents a different kind of narrative and genre, not speaking of his involvement in commercials) and his inclination for the spectacular. Gedeon, on the other hand, is a concentrated, authorial figure who defines the foundations of the future film's shape already in the literary phase. He is somewhat more personal and 
his techniques less conspicuous but he is no less creative and luxurious. Svěrák as a director likes to show off.

Gedeon, on the contrary, retreats into the background, yet despite all simplicity, his is a refined retreat. Svěrák does not mind an "artificial" stylization and constructs external visual attractions -- sometimes to the detriment of the narrative logic and the definition of his characters. Gedeon relies more on the photogenic quality of the natural image which he invests with impressive compositions, as well as the hidden poetry drawn from the immediate contact with reality. His domain is a precise miniature of the everyday situation which he particularizes through a grotesque and poetic exaggeration, through work with telling detail and mood.

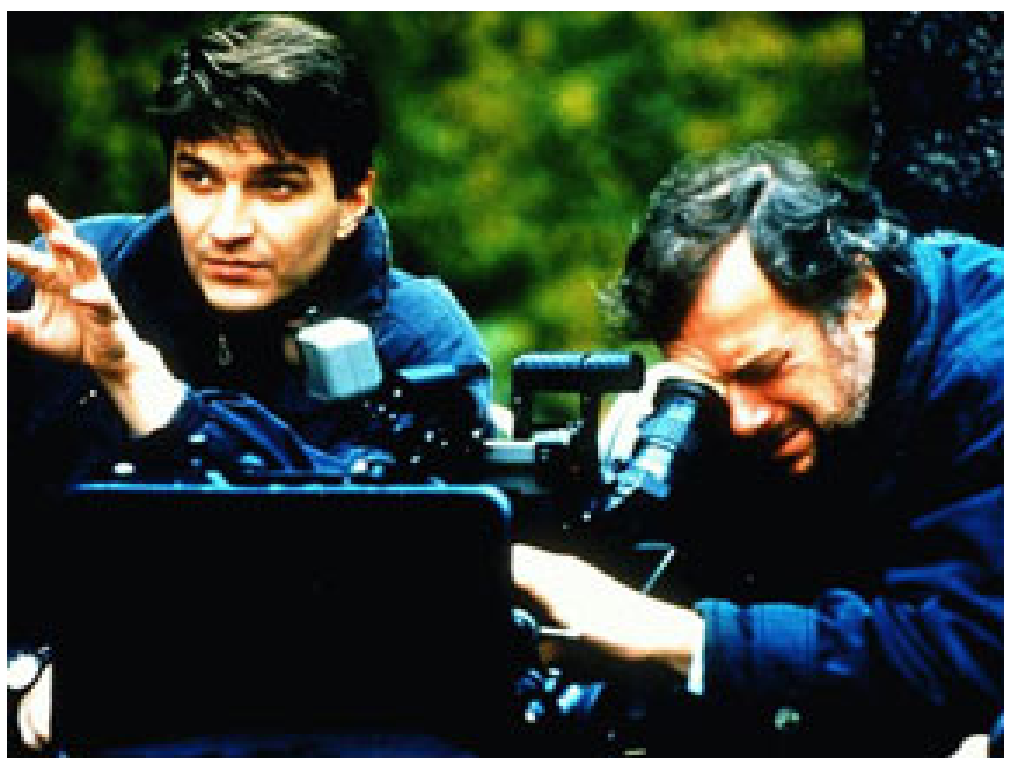

Figure 2: Director Jan Svěrák

Gedeon also has a different subject of enquiry: unlike Svěrák who is fascinated by action and movement, Gedeon is attracted by human behavior and intricate webs of relationships in a seemingly arrested time-space. He subdues the reality in such a subtle way that its transition into the filmic illusion is almost imperceptible. Svěrák, on the other hand, strengthens the illusion by intentionally interrupting it from time to time. For both, however, film is a magical, refreshing game which they can offer to the viewer.

There is no need to overestimate this generation; some of its filmmakers have produced one or two films prized at international festivals. People say that only the third film determines the real talent of a director. Despite this, it seems that the Czech film has, after a longer time again, interesting creative personalities which may excel not only at home but are also able to assert themselves on the international stage. Small film-producing nations, such as the Czech Republic, must particularly respect such talents since they have none to spare.

\section{(Translated by Jan Uhde)}

\section{Notes}

1. The Czechoslovak film was nationalised by the Presidential Decree issued by President Edvard Beneš in August 1945, as the first industrial branch in postwar Czechoslovakia, earlier than strategically important industries, such as banks or mines.

2. The state film monopoly ceased to exist de facto in 1991, with the completion of the first Czech privately produced film The Tank Battalion (Tankový prapor) directed by Vít Olmer and produced by Bonton. The 


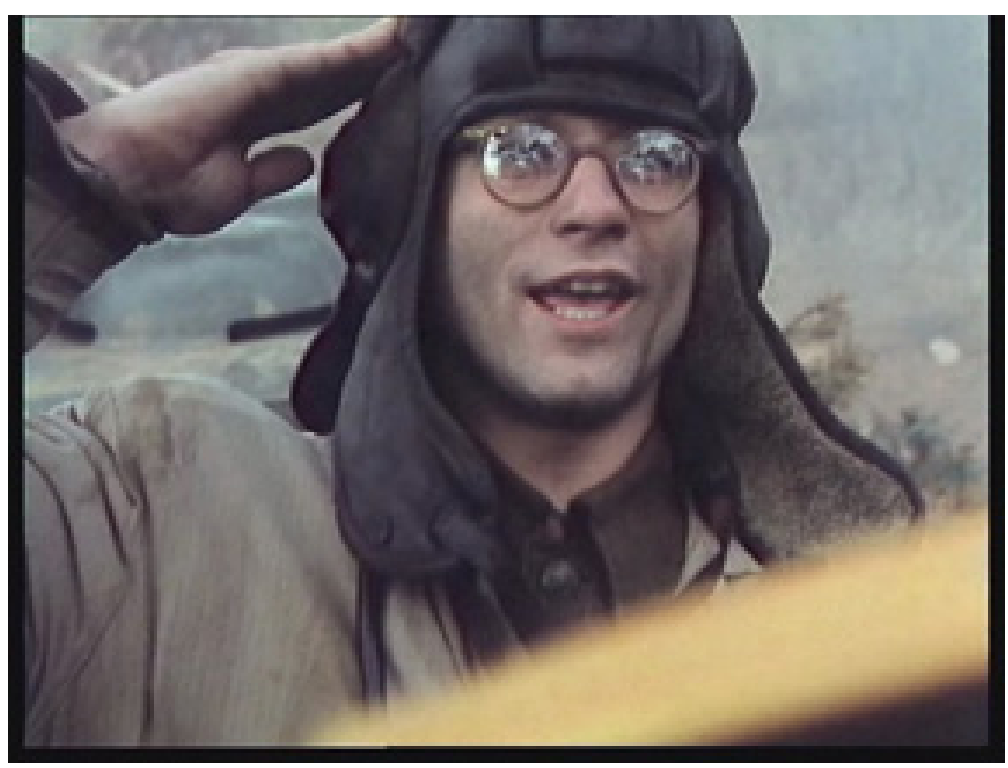

Figure 3: Tank Battalion (dir. Vit Olmer, 1991)

monopoly was abolished de iure in 1992.

3. Czech New Wave also included the following filmmakers: Evald Schorm, Jan Němec, Pavel Juráček, Juraj Herz, Jaromil Jireš, and others. The phenomenon of the Czech film of the 1960s however, was in part indebted to the preceding generation of filmmakers which equally contributed to the world-wide success of the Czech film: Ján Kádár, Elmar Klos, Karel Kachyňa, Vojtěch Jasný, František Vláčil, and others.

4. In the post-1989 period, the Czech Republic (Czechoslovakia before 1993) had been producing an average of 15 feature films annually. The production ebbed in 1992 (only 8 films) but rebounded in 1995 and 1996 (20 films per year). In the 1960s, Czechoslovakia produced between 25-30 films annually. With respect to the reduced home market (Czech Republic has a population of 10- million), this drop can be considered natural. Even when seen in absolute numbers such a reduction is not dramatic. The production decline is also tied to the increased film production costs: Before 1989, the production costs of a feature film in Czechoslovakia was approximately CZK 5 million (USD 160,000), while today's cost have risen to CZK 20 million (approx. USD 650,000). The most expensive film in the history of the Czech film production has been Jan Svěrák's Accumulator I (Akumulátor I., 1994, 40 Million CZK, or 1.3 million USD). Logically, the major part of the Czech feature production consists of strictly commercial films, particularly in the early 1990s. Recently however, the production of films with artistic ambitions has been on the increase.

5. During the 1980s, the annual theatrical attendance was 4-5 per capita; this figure dropped to 1 in 1996. Thanks to the traditional interest of Czech viewers in home production, Czech films have maintained a relatively decent audience. The most successful Czech film has been the Tank Battalion (Tankový prapor, 1991), with over 2 million viewers; Svěrák's successful Kolya may top this mark. (For comparison, the most successful film of the 1980s, Menzel's My Sweet Little Village (Vesničko má, středisková, 1980), was seen by almost 4,5 million viewers.)

6. Vera Chytilová, one of the most vocal opponents of privatisation and a champion for the state protection of film production, shot her latest film 1992, a "communal" satire called Heritage (Dědictví, aneb Kurvahošigutntag). Jiří Menzel's most recent picture, Life and Extraordinary Adventures of the Private Ivan Chonkin (Život a neobyčejná dobrodružství vojáka Ivana Čonkina), dates back to 1993.

7. This 1989-made drama presents a suggestive portrait of a complex-ridden young girl developing into a cold, cynical woman who cunningly manipulates those around her, using the others' weaknesses, passivity and incompetence. Through her demonical heroine the director (b. 1960) illustrates how evil breeds more 
evil.

8. This film by Zdeněk Tyc (b. 1956) film, shot in widescreen monochrome, is a ballad about an unfulfilled desire, about freedom and rebellion, resulting into a tragedy. Its main character, Vojtěch, is the being of a transparent animality and unbridled nature who refuses to be subdued by society's conventions, nor customs of the village togetherness into which he returns to fulfill his destiny. The story of this stylistically refined picture is set into the post-World War II period (1946); the film excels through its artistically conceived landscape photography and the natural acting talent of Petr Forman (a son of Miloš Forman) in the film's title role.

9. Jan Svěrák (b. 1965), a FAMU graduate (documentary film) is at present the most successful and most productive Czech filmmaker. His attractive yet artistically accomplished projects have been rewarded by the lasting interest of the audiences, festival juries and producers. His ambitions evidently reach beyond the borders of Czech Republic. In his films he strives to address international audience; for this reason he intends to shoot his next film in English. Svěrák's most important films have been based on scripts of his father Zdeněk, the best Czech scriptwriter today. This applies to Jan Svěrák's first feature Elementary School (Obecná škola, 1991; US Academy Award nomination); and Kolya (Kolja, 1996, six US Academy Awards, 1996). Jan Svěrák also received a Student Oscar, for his 1988 film Ropáci, a brilliant mystification with ecological theme. His other features include the sci-fi parody Accumulator I (Akumulátor I, 1994) and Ride (Jizda, 1994, a Czech version of the famous Easy Rider). This is the only film which he also wrote; it quickly became a cult film of the Czech youth.

10. Saša Gedeon (b. 1970) graduated from FAMU (direction). He is probably the most individual talent among the Czech directors today. He was noticed early for his school films. His short Closed due to Family Mourning (Zavřeno pro rodinný smutek, 1991) received the Main Prize at the Student Film Festival in Tokyo in 1993 which involved a grant for shooting of a medium-length film; this project eventually grew into the feature Indian Summer (Indiánské léto, 1995) which was rewarded at several festivals, including the IFF in Cairo (1995) and Cottbus, Germany (1995). Indian Summer is a lyrical tragicomedy focusing on the relationship of Marie and Klára, two cousins with character differences who are spending the end of their vacations with their grandmother in the country. They experience difficulties with boys and with themselves. The director's subtle miniature of precisely observed everyday situations and his sense for a grotesque and poetic exaggeration, his work with photographic detail and mood, effective image composition, this all helps to make the viewing of this film a unique experience.

\section{Author Information}

Jiří VORÁČ is Chair of the Film Studies, at the Department of Theatre and Film Studies, Faculty of Arts, Masaryk University Brno, Czech Republic. His area of specialization includes Czech film history after 1945, interpretation and adaptation issues and film criticism. He wrote the book Czech and Slovak Film Directors in Exile (Palacký University, Olomouc, CR), and has contributed reviews to Film a doba, Iluminace and other publications. 